Péter Sasvári, Bálint Teleki, Anna Urbanovics

\title{
How to Go on University Professors? Or the Minimum Publication Requirement in Social Sciences
}

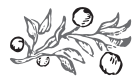

\section{Summary}

The most recent guideline of the Hungarian Accreditation Committee about the applications submitted by university professors subject to the requirements published in July 2019 entered into force on 1 September 2019. This document establishes new general minimum publication requirements for applicants, supplemented by special requirements for the specific areas. These requirements were necessitated by changes in the international academic paradigm, which encourages the issue of Q1 and Q2 level publications. The purpose of this paper is to examine compliance with these requirements by university professors who received their title in the past three years. The findings show that only 23 per cent comply fully with the general minimum requirements, with a 40 per cent full compliance with the supplementary requirements of the field of economics and business, and a 10 per cent in the field of social sciences.

Journal of Economic Literature (JEL) codes: A10, Z00

Keywords: university professor, publication requirements, Hungarian Accreditation Committee, Scopus

Péter Sasvári PhD habil, Associate Professor, National University of Public Service (sasvari.peter@uni-nke.hu); BÁLInt Teleki, PhD student, National University of Public Service (teleki.balint@uni-nke.hu), Anna Urbanovics, PhD student, National University of Public Service (Urbanovics.Anna@uni-nke.hu). 


\section{INTRODUCTION}

In June 2019, the Hungarian Accreditation Committee (HAC) accepted its most recent guideline regarding the evaluation of university professors' applications (Resolution No. 2019/5/VII/4. of the HAC on the Guidelines to the preparation and evaluation of university professors' applications; $\mathrm{MAB}, 2019)$, which entered into force on 1 September 2019. The guidelines set minimum, general and special requirements for academic and university lecturers' performance. These requirements fit into a pattern of significant changes in the international academic community, and lead to a paradigm change in measuring value.

The various international academic fields attract an increasing number of participants, and consequently success and recognition increasingly depend on the number of publications in journals (Wuchty et al., 2007). Today, it is not nearly enough to publish papers in a one's country, because in an increasingly transparent and digitalised world of intensifying competition, the international rankings are set by international publication performance. The model of competition-based financing has also been adopted in Hungary, on each and every step of the ladder of the academic hierarchy. This new system of financing requires, on the one hand, focus on results, and on the other, devoted efforts by all the institutions and employees of the Hungarian system of higher education towards a systematic and transparent evaluation of systems, excellence in the international and Hungarian arena, and for the resources and financial support (Kozma, 2011).

In Hungary academic advancement is based on performance and individual merits. One can work his or her way up the career ladder in the following steps: obtain a PhD degree (Kiss, 2014); habilitate (Dobos et al., 2016); become a 'doctor of the Academy' - referring to the Hungarian Academy of Sciences (HAS), (Zalai, 2006) and finally obtain the title 'Academician' (a full or a corresponding member) (Polónyi, 2010). Selection based on professional merits is based on the HAC's evaluation of applications submitted for a position as a university professors or as a doctor of the Academy (Bazsa, 2017). In parallel with the aforementioned steps, one is also promoted at his or her job as follows: from an assistant lecturer he or she becomes an assistant professor, then an associate professor and finally a university professor, the highest achievable rank in Hungary.

The purpose of this paper is to examine the scientific performance of researchers who have received a university professor's title in the past three years, in light of the minimum requirements of the new HAC guidelines. Then a group of university professors are compared to a groups of "Academic Doctors" and Academicians.

\section{THEORETICAL BACKGROUND}

The international scientific change of paradigm is a combination of several processes, including competition-based financing, which is gaining ground internationally and in Hungary (Polónyi, 2012). 
Since its 2004 accession to the European Union, Hungary has been an active participant in European common research, in constant transformation and rapid development, which defines the areas the Member States pursue to carry on with their scientific activity through the institutions of the European Union based on similar or identical requirements and values. One of the best known programmes is the Horizon 2020 of the European Commission, financed under the European Research Council's (ERC) research grant system. The most important characteristic of the ERC research grants is their bottom-up nature, which means that researchers compete in their own research fields without restriction, since there are no pre-determined research subjects. The ERC is open for all research fields, including engineering and natural sciences, social sciences and medical studies. Another important characteristic is that it completely relies on international researcher excellence, based on the quality and quantity of the publications registered in the Scopus international database, and the number of linked citations. The international scientific rankings in their systems also build upon these scientific excellence criteria, whose bases are also the publications registered in either the Scopus, or the Clarivate Analytics Web of Science (WoS). These databases set very similar criteria for authors and journals, and evaluate their indexed publications, and for this reason, they constitute an optimum basis for the evaluation of international rankings and research grants.

There are two major examples of Hungarian research grants of nationwide importance which require international researcher excellence. The first one is the Research Field Excellence Programme (Tématerületi Kiválósági Program), and the second is the Frontline - Researcher Excellence Programme (Élvonal - Kutatói Kiválósági Program). Both require that the purpose of financing should be to obtain internationally important research results, and both expect international researcher excellence. The Frontline system is much more similar to the ERC with regard to its purpose and applicants, as it intends to support researchers of the most outstanding results. The set criteria include minimum international publication requirements as a supplement to a professional review. Similarly, experts recommend minimum requirements regarding the habilitation processes (Dusek, 2019; Papp, 2019). In case minimum requirements are set, the role of subjective judgment is reduced by the decisions on research grants (Balaton, 2019).

The common criterion of the requirements of research grants is to have publications qualified by the Scimago Journal Rank (SJR) international journal ranking. An important element of the transition is that the SJR-value of journals (and thus of the publications) is presented on the ranking - within the individual research fields - in four classes of identical thresholds - at the service provider, in the Repository of Hungarian Scientific Works (RHSA, Magyar Tudományos Múvek Tára, MTMT) - from the top 25 per cent to the bottom 25 per cent. This is called quartile ranking (Q1: best 25\%; Q2: 25-50\%; Q3: 50-75\%; Q4: 75-100\%), and allows - at least theoretically - direct comparison between journals and publications in different fields of science and profession (on the basis of their ranking in theirrespective fields, Soós, 2017). SJR is a major factor in the systems THE (World University Rankings, Times Higher Educa- 
tion), QS (QS World University Rankings), and ERC research grants.

Besides the financing model and digitalisation, another paradigm change that has taken place in scientific publication (Nagy, 2016) is that the scientific discourse has shifted from books (monographies, edited and synthetic books) to the world of journals (Larsen and Von Ins, 2010). This trend began in the field of natural sciences, but social sciences have also lined up and, moreover, certain effects are even observable in liberal arts (Csapó, 2011).

\section{Change OF PARADIgM IN THE EVALUATION OF UNIVERSITY RESEARCH GRANTS}

If one reads the call for papers, it is clear that international research excellence is increasingly required, and it is no longer a privilege of a reserve group, but a generally accepted, obligatory requirement for all members of the scientific community (Gazizova et al., 2016). These ambitions are reflected in Resolution No. 2019/5/ $\mathrm{VII} / 4$. of the HAC on the Guidelines to the preparation and evaluation of university professors' applications, published in June 2019, a document concerning university professors' applications, and laying down requirements which had previously been included in only certain excellence programmes. This is a noteworthy change as it is a systematic integration of the requirements of high-standard international journals. The approved document contains both general and specific criteria on academic activities. In addition to the requirements, the guidelines also include elements of the specific traditions and sets of values of the individual fields, which in certain cases results in stricter, in other cases more lenient requirements. Consequently, there are basically two ways of interpretation; one of them is that the general and special requirements are to be considered together, and the fulfilment of both is expected; the other is that the applicant has to prioritise the special requirements where they exist. In this paper the special requirements are prioritised where they are specified besides the general requirements.

Based on Figure 1 the general requirements of scientific activity are as follows (set B):

"The application should present that the applicant has internationally recognised foreign-language publications with scientific results. As a minimum requirement, the applicant should have at least two foreign-language Q1 or Q2 level papers (singular, first or last, or corresponding), or the applicant should be the author of at least one monography published by a recognised international publisher" (MAB, 2019, p. 12).

According to the general requirements set in the guidelines, the minimum requirement is two foreign-language $\mathrm{Q} 1$ or $\mathrm{Q} 2$ level papers included in the journal ranking of the SJR. The expression "singular, first or last, or corresponding author" refers to papers by key author(s), where the role and the contribution of the applicant in the qualified publication are shown. In STEM (science, technology, engineering, and medicine) fields, in internationally highly qualified papers, it is quite often that hundreds or even thousands of co-authors cooperate (Castelvecchi, 2015). This is why only the papers of key author(s) are accepted for the purposes of research grants. The 
Figure 1: Academic minimum performance requirements for university professors based on the SJR categorisation

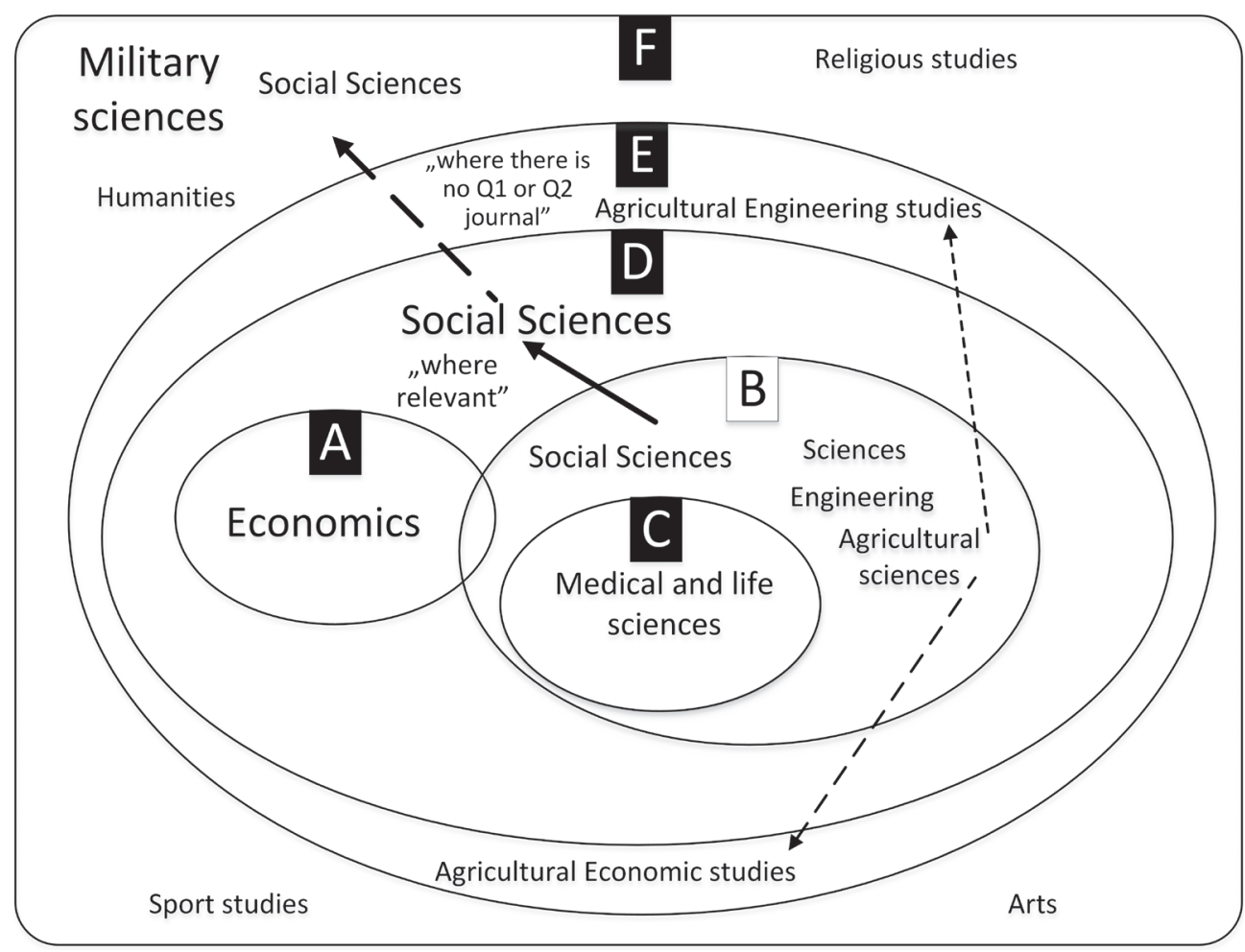

Source: Authors'own elaboration

definition of papers by singular authors is the easiest; in this case the given publication belongs to only one author. The first author is usually the person who has contributed most to research and the writing of the manuscript. The last author is traditionally the lead researcher who assumes responsibility for the research project and often the key actor of the research field. The role of the corresponding author is to keep contact with the editorial board, as a permanent contact person (Dance, 2012).

The representatives of natural sciences, engineering, and agricultural sciences have undertaken to fully comply with these conditions, so they are listed in set B. Medicine and health sciences marked with letter $\mathrm{C}$ have tightened the general requirements by only accepting level Q1 papers, and the applicant is also required to prove their key role.

In social sciences the requirements are special and fragmented, as originally this field was listed in the set marked with letter B, i.e. accepting the general requirements, however, they have made the requirements less strict by adding the phrase "where it is relevant" and therefore now they are listed in set D. Social sciences, in accordance with the nomenclature of the field, include the following: legal sciences and state 
administration, military sciences, administrative sciences, media and communication sciences, political sciences, policing and law enforcement sciences, and sociological sciences. In these fields of science, university professor applicants have to comply with the following special requirement: "Publication activity, professional papers: two foreign-language publications written as singular, first or last author (where relevant), published in $\mathrm{Q} 1$ or $\mathrm{Q} 2$ level journals. In fields without $\mathrm{Q} 1$ or $\mathrm{Q} 2$ level journals, leading international peer-reviewed journals of the field can be taken into consideration" (MAB, 2019, p. 17).

Beside the general minimum requirements applicable to social sciences, the representatives of business studies have specified additional special requirements (set A). Regulations on business studies are applicable to business and organisational studies, economics, and regional studies as follows: "The applicant has to demonstrate that they have achieved scientific results and published them in internationally recognised foreign-language publications. As a minimum requirement, the applicant should be the author of two foreign-language Q1 or Q2 level papers (and the singular or first author of at least one)" (MAB, 2019, p. 17).

The special requirements set for business studies are interesting because the applicant must have a key role (be the singular or first author) in one of the two expected Q1 or Q2 level papers, but there are no requirements regarding the role of the author of the other paper. Therefore, this wording represents limitation and easing at the same time.

Group E lists the interface fields between agricultural sciences and engineering or economics, where the following special requirement is applicable: "In the interface between agriculture and economics: one paper published in a Q1 or Q2 level journal is equivalent to a study written with no more than one co-author and included in a Hungarian book or to three chapters in a book. In the interface between agriculture and engineering: one of the papers published in a $\mathrm{Q} 1$ or Q2 level journal is equivalent to three foreign-language papers published in a journal which has an international advisory body, and is listed by the HAS sectional (journals Board IV, Agricultural Studies); or to an implemented engineering project (patent, know-how, machinery, or technical equipment); or to one foreign-language book or a chapter in a book" (MAB, 2019, p. 14).

Group (F) contains the scientific fields which fully exempt applicants from writing Q1 and Q2 level papers, and replace this requirement by special results which are more in line with their own publication traditions. These include liberal arts, theology, arts, sports, military sciences, and social sciences. As presented in Figure 1, the special requirements are as follows:

"In fields without any Q1 or Q2 level journals, the leading peer-reviewed international journals of the field may be taken into consideration" (Liberal Arts) (MAB, 2019, p. 15).

"[...] the applicant should be the author of at least 30 peer-reviewed papers" (in theology, MAB, 2019, p. 12).

"[...] the applicant should be an internationally recognised artist" (in arts, MAB, 2019, p. 12). 
"[...] regular publication in Hungarian and in foreign languages in the field" (sport, MAB, 2019, p. 12).

"Publication and professional papers: two papers published as a singular or first or last author in foreign-language publications published in leading international peer-reviewed journals of the field on military sciences" (military sciences, MAB, 2019, p. 18).

"In fields without Q1 or Q2 level journals, leading peer-reviewed international journals of the field may be taken into consideration" (social sciences, MAB, 2019, p. 17).

The common element in these regulations is that in these fields there are no listed Q1 or Q2 level journals, and therefore other leading international journals, field-specific publications, or works of art are accepted from the applicants. Note that the special requirement set in social sciences allows consideration for "leading peer-reviewed journals of the field" in certain cases. These journals are listed in the rankings approved by the scientific committees of Board IX of HAS, and include journals that do not have any SJR rank but are prestigious. Finally, the special requirement specified in military sciences relieves the applicants from writing Q1 or Q2 level papers.

The special requirements applicable to social sciences are eased at two points in comparison to the general requirements. They were transferred from Group B to Group D because of the phrase "where relevant", and they were then transferred from the Group D to Group F, i.e. the group with the most lenient regulations, because of the phrase "without Q1 or Q2 level journals", as this excluded consideration for "leading international peer-reviewed journals in the field". Note that in accordance with the classification, legal sciences and state administration, media and communications, political and sociological studies have their own lists in the SJR journal ranking system. The three groups of business studies intend to distance themselves from the aforementioned group of social sciences in setting requirements for university professor applicants with their different regulations. In military sciences the regulatory requirement of publications in SJR-ranked journals is disregarded. Similarly, in policing and law enforcement studies, the SJR journal list is not applied, and no special requirements have been set for their applicants. The phrase "without Q1 or Q2 level journals" clearly apply to the latter two fields, and thus similarly to military sciences, applicants are judged in accordance with the regulations laid down in Group F.

\section{RESEARGH}

This analysis covers a total of 105 university professors who have received their titles in social sciences in the past three years. Comparisons were made in accordance with the general and special requirements of the guidelines on scientific performance (publication). Compliance with the special requirements of the groups in business studies and social sciences was also examined. 
The guidelines do not set the requirements on the basis of the classification given by HAS's scientific committees but according to the classification of scientific fields. Accordingly, the guidelines classify social sciences as follows:

Economic sciences

- Business and organisational studies

- Economics

- Regional studies

Social science

- Legal and state sciences

- Military sciences

- Administrative sciences

- Media and communication studies

- Political sciences

- Policing and law enforcement sciences

- Sociological sciences

Board IX of HAS has the following scientific committees:

- Committee of Legal and State Sciences (LAW)

- Committee of the Economics of Human Resources (CEHR)

- Committee of Business Studies (CBS)

- Committee of Military Sciences (CMS)

- Committee of Economics (ECO)

- Committee of International and Development Studies (SCIDS)

- Committee of Political Sciences (POL)

- Committee of Regional Studies (CRS)

- Committee of Statistics and Future Studies (CSFS)

- Committee of Sociological Sciences (SOC)

The 215 Academic Doctors and 30 academicians active in the scientific fields registered by Board IX of HAS were added to the above/referenced university professors. The researchers' publication data was downloaded from the Hungarian national reference database (RHSA), mandatorily used and regularly updated by everybody with a scientific degree or position pursuant to Act XL of 1994 on the Hungarian Academy of Sciences. The website including a classification of the members of the General Assembly of HAS, and the CV's were also consulted during the research. The data was analysed by descriptive statistical methods.

The data of Q1 and Q2 level papers required by the guidelines were downloaded from the RHSA system. The system assigns the quartile of a given paper published in a journal depending on the rankings of the given year (except for the current year). In July each year, the RHSA system annually synchronises the SJR quartiles assigned in the given year. In the current year the quartiles of the preceding year are automatically assigned but when the new rankings are published, they are automatically overwritten. As on the Scimago website the quartiles assigned between 1996 and 2018 are found, the papers published in 2019 are assigned the 2018 quartiles. This function has been working since 2016 in RHSA1, and since 2018 in RHSA2. 


\section{FINDINGS}

Figure 2 gives a general picture of Q1 and Q2 level papers by professors who have received their titles in the last three years.

Figure 2: General minimum requirements relating to SJR ranked papers by university professors $(n=105)$

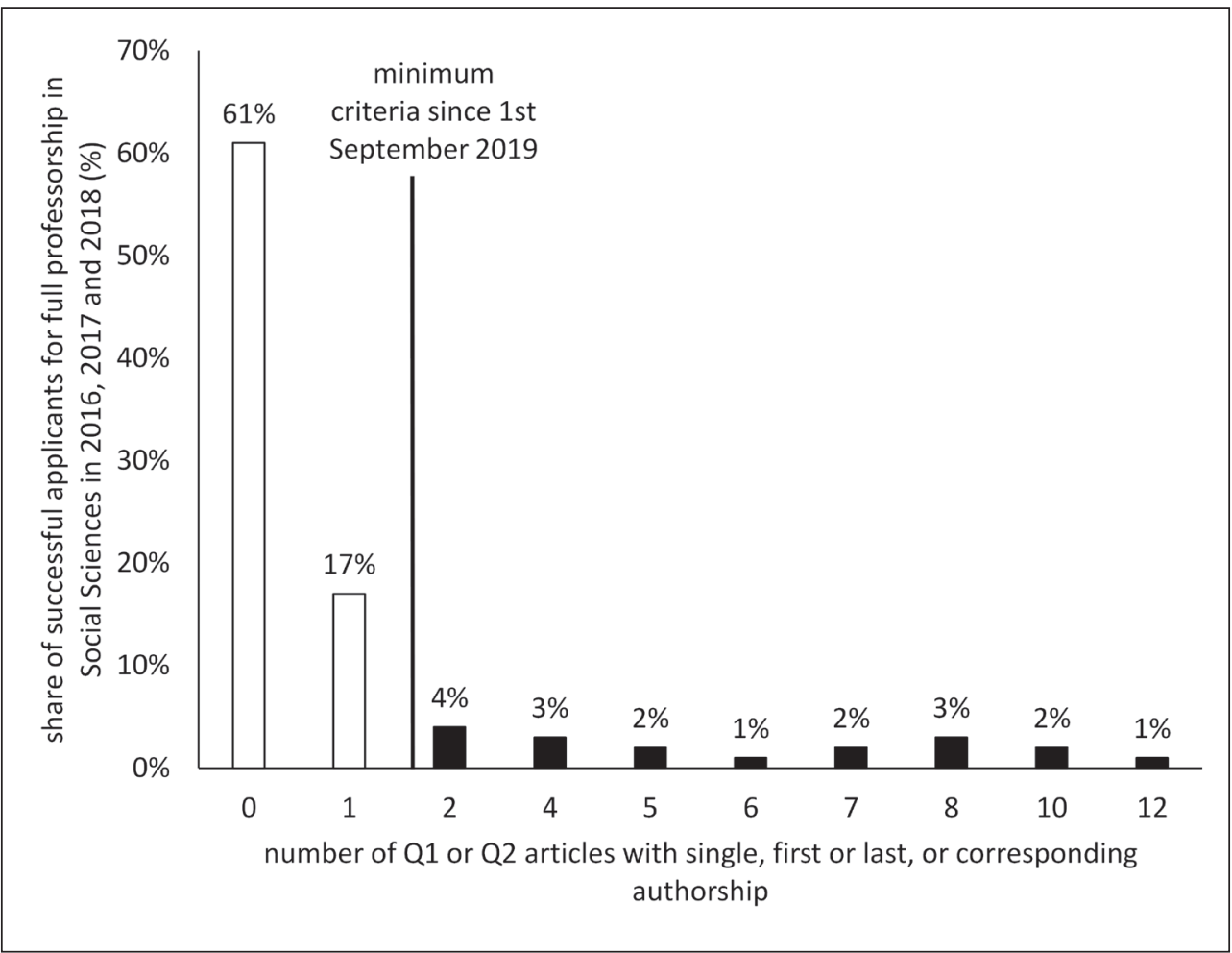

Source: Authors' own elaboration

The figure clearly shows that the ratio of professors who have not published any such paper is high (61\%; 64 persons), and a further 17 per cent (18 persons) only have one such a paper per person. Therefore, the ratio of those in full compliance with the requirements is only 22 per cent (23 persons), of them 4 per cent ( 4 persons) has two such papers per person. The highest number on the list is 12 papers per person, accomplished by a single person. It is clear that before the introduction of the requirements, the number of $\mathrm{Q} 1$ and $\mathrm{Q} 2$ level papers was less relevant or less criteria were be taken into account.

In the analysed sample, 83 are general assembly members in a scientific committee of Board IX of HAS. Figure 3 shows the number of university professors who are general assembly members in each scientific committee. 
Péter Sasvári, Bálint Teleki, Anna Urbanovics: How to Go on University Professors?

Figure 3: General minimum requirements relating to SJR ranked papers by university professors, in a breakdown by the scientific committees of Board IX of HAS ( $n=83)$

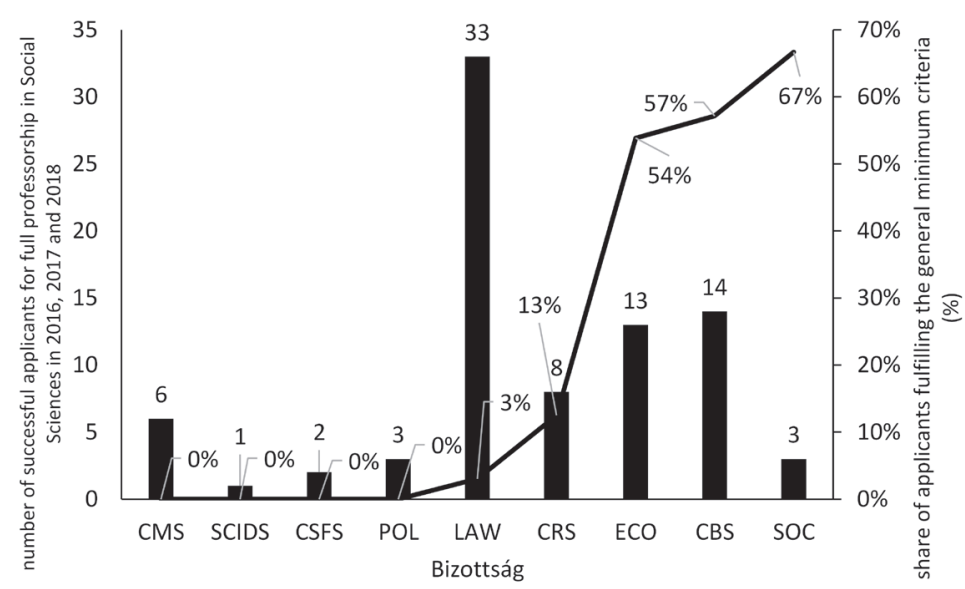

number of successful applicants between 2016 and 2018

_ share of applicants fulfilling the general minimum criteria

Source: Authors'own elaboration

Figure 4: General minimum requirements relating to SJR ranked papers by university professors, in an institutional breakdown $(n=82)^{1}$

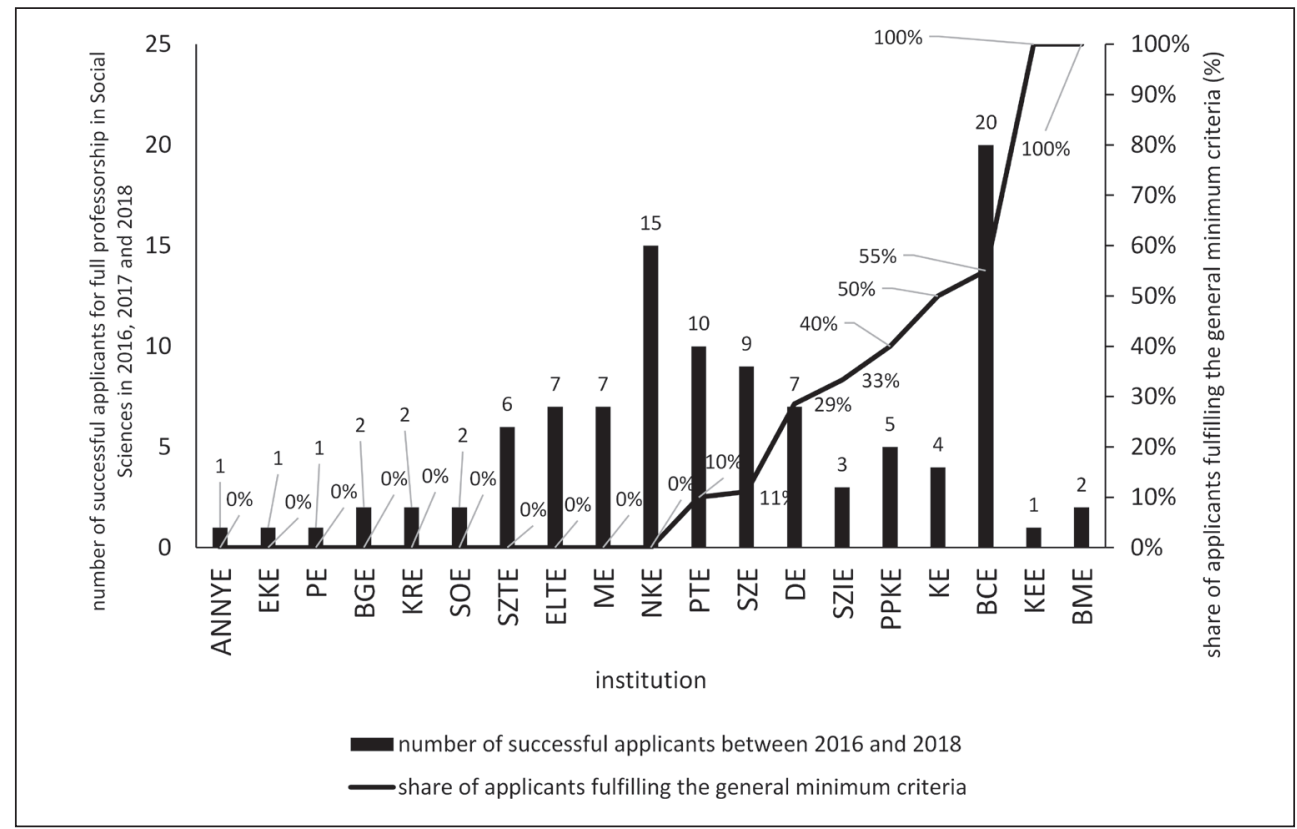

Source: Authors'own elaboration 
Figure 4 shows compliance by the individual higher educational institutions with the general publication requirements. This makes us conclude that these institutions traditionally have considerably higher requirements for international scientific activity by their professors. In the case of the Budapest Technical University, this is explained by the institution's strong ties to engineering and by the fact that the prevailing WoS- and SJR-type international publication performance is a fundamental requirement also for employees conducting research in social sciences (BME GTK, 2018). Among the institutions, BCE stands out as the only university with a higher number of lecturers who have obtained the title of a university professor, including 11 persons who fully comply with the general requirements.

Figure 5: General minimum requirements relating to SJR ranked papers by university professor, in an age spectrum breakdown $(n=90)$

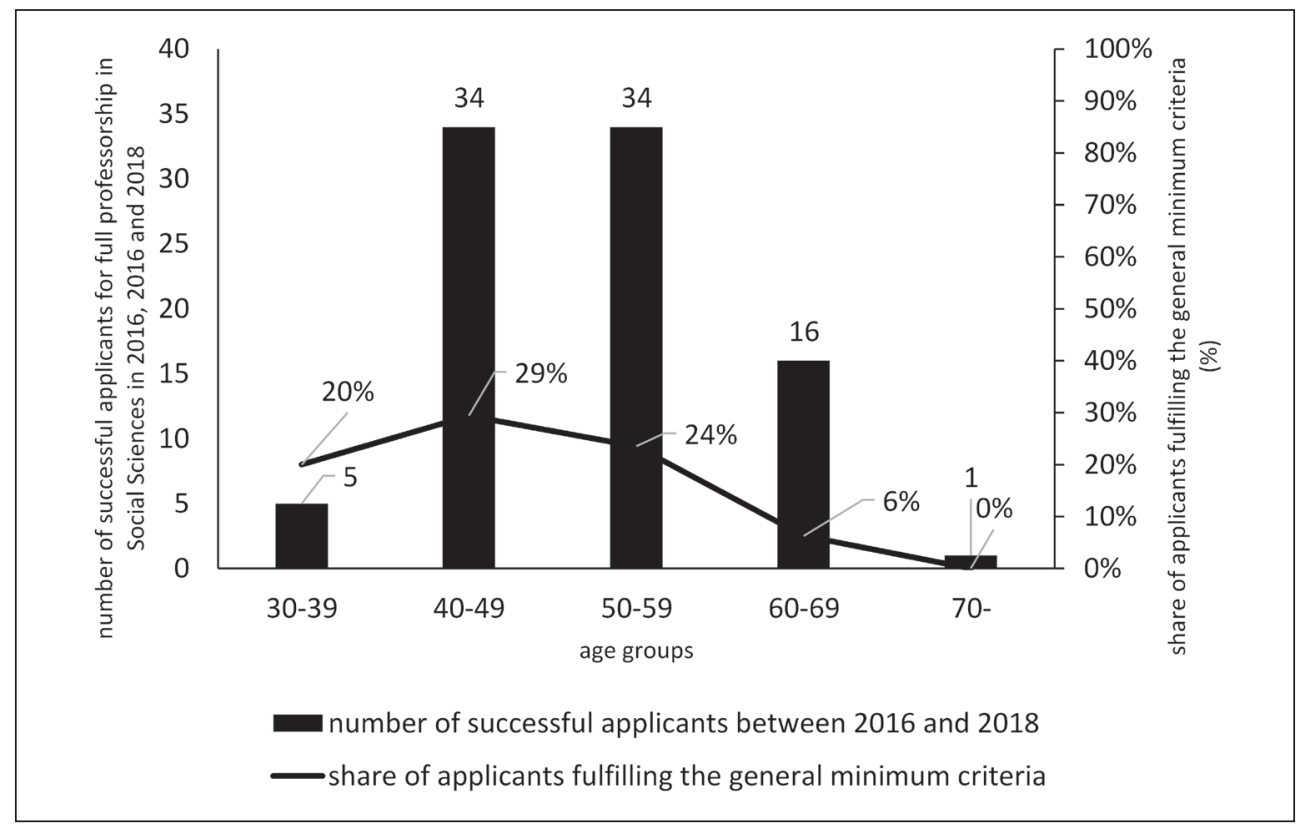

Source: Authors' own elaboration

In the evaluation of scientific achievements, in the qualification of scientists, and in particular, in the funding of research and the evaluation of the relevant applications, more recently there has been a marked shift across the world towards a quantitative approach, along with a definite trend in favour of publishing articles and references in journals at the expense of scientific books (Csaba et al., 2014). The financing of research is in many cases age-dependent (e.g. research entry initiated by junior researcher, post-doctoral junior excellence grant), an furthermore, performance is mostly subject to publication in journals, and this partially explains that publications in SJR-type journals are characteristic for junior researchers. 
Researchers in economic sciences are subject to slightly different requirements applicable in the guidelines on university professors' applications. Figure 6 depicts special requirements, taking the three areas of the field into consideration. The latter are business and organisational sciences, economics, and regional sciences.

Figure 6: Special minimum requirements in economics in relation to SJR-ranked papers by university professors $(n=49)$

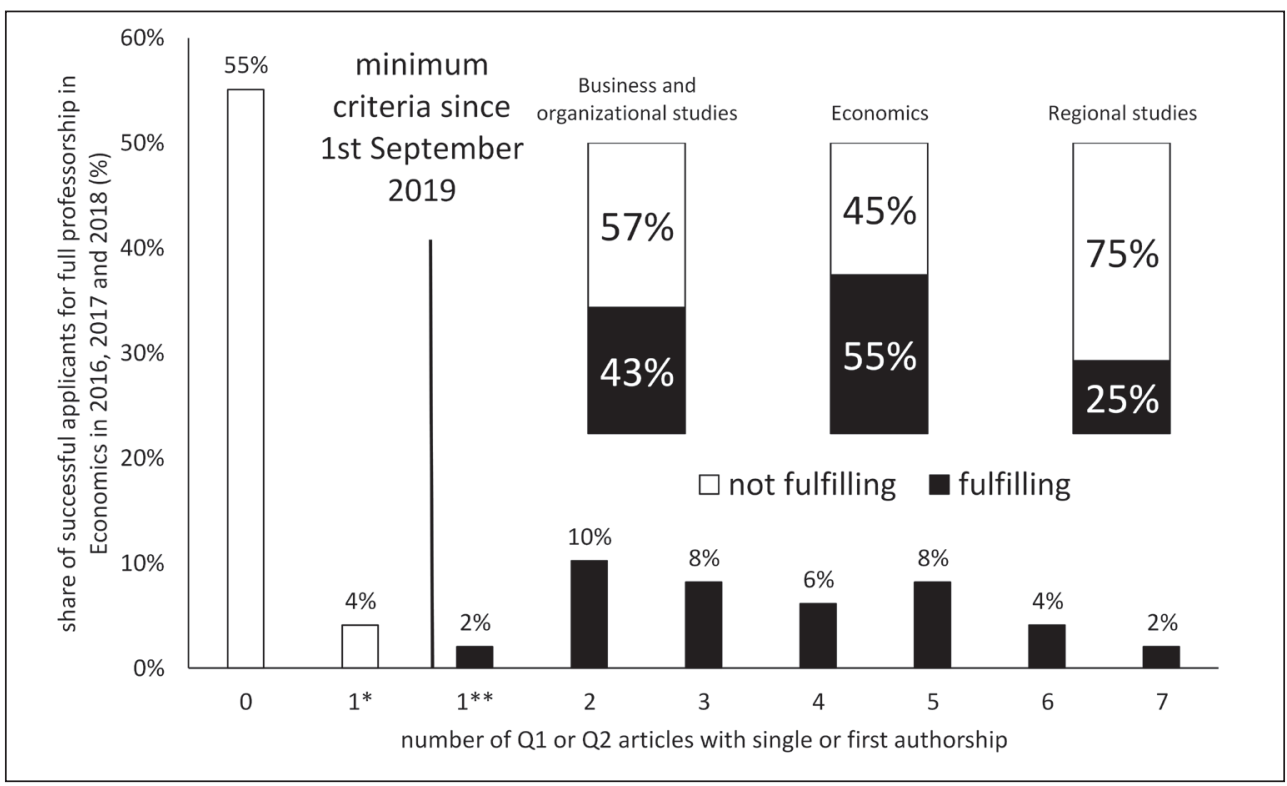

Source: Authors'own elaboration

The analysis of compliance with the special requirements was conducted for 49 university professors in economic studies. The column marked by $1^{*}$ shows the number of professors who have only one $\mathrm{Q} 1$ or $\mathrm{Q} 2$ level paper as a singular or first author. The column marked by $1^{* *}$ shows the ratio of professors within the group of the analysed university professors who, besides having one Q1 or Q2 level paper published as a singular or first author, also have another Q1 or Q2 level paper.

Different measures were performed in the three areas. The most populous group is that of business and organisational studies (30 persons), followed by regional studies (11 persons), and economics (8 persons). Of these groups, university professors in economics have the best results.

These ratios can be explained by the special nature of the individual areas: in terms of subject and methodology, economics is the closest to natural sciences and its publishing traditions are similar to those of STEM sciences (Redden, 2018), while the other two areas tend to use the methodology of social sciences. 
Figure 7: Publication habits of university professors in economics

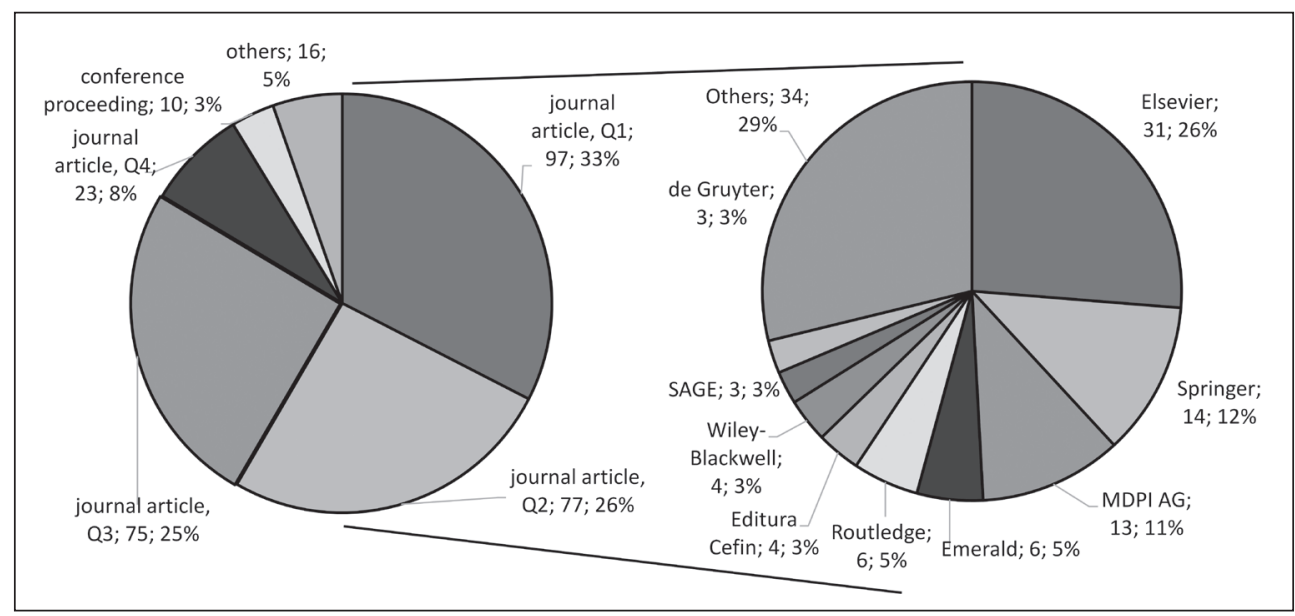

Source: Authors'own elaboration

Overall, it is a favourable trend that the university professors who publish papers in internationally recognised journals are more likely to choose Q1 or Q2 level journals; the ratio of the latter is nearly 60 per cent. This allows us to conclude that the basic problem is not the absence of information on the journal to publish in but the fact that proportionately fewer of them intend to conduct research resulting in SJRranked publications.

Elsevier, Springer, Wiley-Blackwell and SAGE are the publishers with the highest share (Larivière et al., 2015), which suggests that researchers active in economics tend to publish in journals which are internationally significant and have a large impact and share. It should be emphasised here that the EISZ (Elektronikus Információszolgáltatás - Electronic Information Service) has concluded a national consortium agreement - regarding Open Access publication - with the Springer, Wiley-Blackwell and Elsevier publishing companies. An analysis of the special requirements of the three areas of economic studies was followed by an analysis of the special requirements applicable to social sciences.

The 51 persons involved in research are subject to special requirements in social sciences. In comparison with economic studies, the ratio of those who do not have any Q1 or Q2 level papers is considerably higher (78\%; 40 persons), and 12 per cent (6 persons) only have one such paper. Of those in full compliance with the requirements, only 2 per cent ( 1 person) has 2 papers, 2 per cent ( 1 person) has 4 papers, and 4 per cent ( 2 persons) has 5 papers, while the best result ( 6 papers) was achieved by a single university professor.

In a breakdown by research areas, four of the six groups none of the professors had any Q1 or Q2 level publication. These groups comprise administrative sciences, media and communication sciences, political sciences, and policing and law enforcement sciences, and relatively few (a total of 9) new university professors have received 
their titles in these fields in the past three years. Legal sciences and public administration is a significantly larger group, including 92 per cent ( 35 persons) who have not, and 8 per cent ( 3 persons) who have complied with the special requirements. In social sciences, sociology is outstanding with a compliance rate of 50 per cent.

Figure 8: Special minimum requirements in social sciences relating to SJR-ranked papers by university professors $(n=51)$

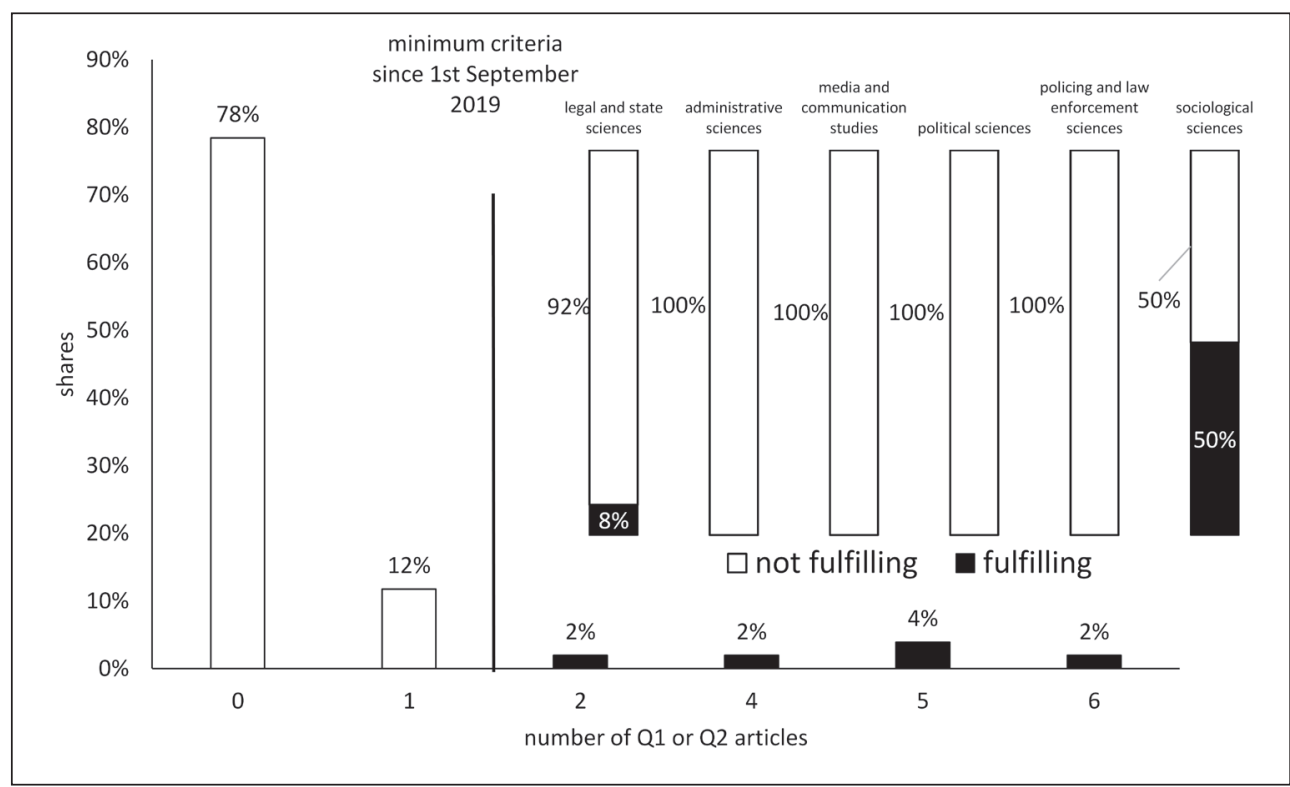

Source: Authors'own elaboration

Figure 9: Publication habits of university professors in social sciences

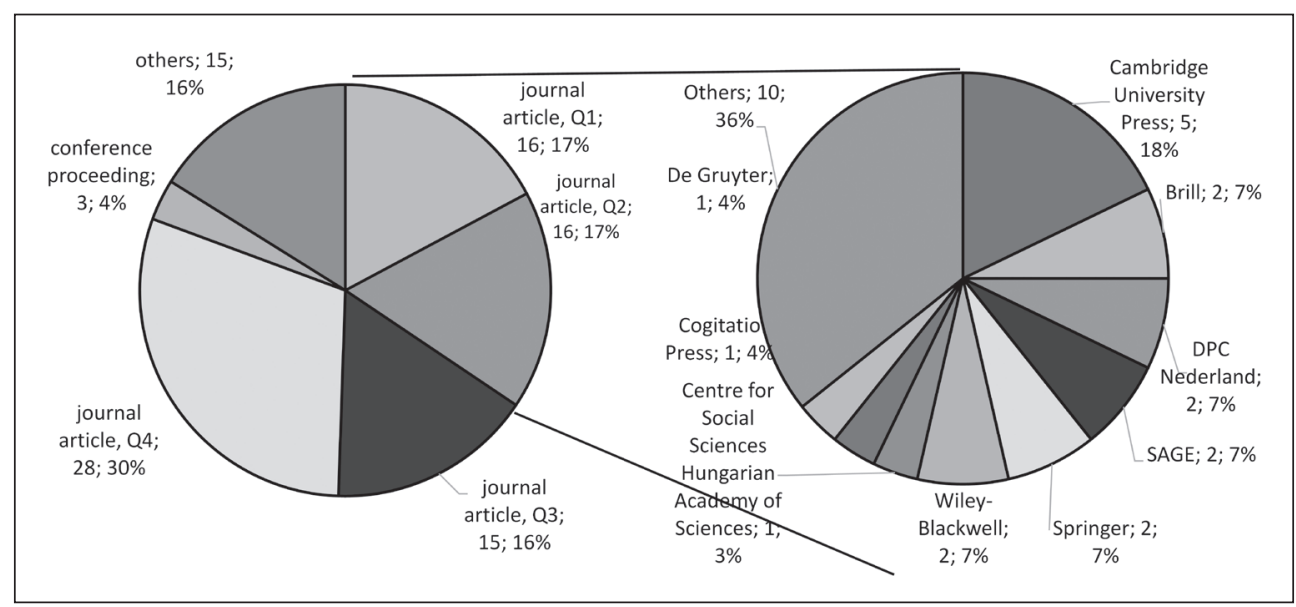

Source: Authors'own elaboration 
As shown in Figure 9, university professors in social sciences also differ from those in economic studies in terms of publication habits. The ratios of papers published in the appropriate journals are 17, 17, 16 and 30 on the levels Q1, Q2, Q3 and Q4, respectively. In addition, conference papers represent 4 per cent, and other publications, such as book chapters, share 16 per cent.. On the one hand, the representatives of social sciences prefer the lower quartiles of Q3 and Q4 level journals (46\%), which is non-compliant with the guideline requirements of Q1 and Q2 level publications.

As a result of the shift towards Q3 and Q4 level publications, big international publishers have also lost significance among the surveyed university professors.

An analysis of Academic Doctors and academicians at Board IX of HAS through the general and special minimum SJR publication requirements

The new guidelines of HAC regarding university professor applications, and its new minimum publication requirements are expected to bring about changes not only at the level of university professors. As the levels of scientific promotion, including the obtaining of scientific degrees and job titles, are interrelated, it is presumed that the requirements have an impact on Academic Doctors and on academicians. Presuming that the final goal of all researchers and lecturers is to obtain these two scientific degrees, they organise their work in a way to comply with the relevant requirements. The Academic Doctors and academicians are organised into committees at HAS, and a researcher may simultaneously be a member in several committees. In this case, credits were assigned to them for their publication performance in both committees. In line with the aforementioned, Table 1 summarizes the analysis of the rankings of HAS Academic Doctors and academicians according to the minimum publication requirements declared in the new guideline regarding new university professors.

As shown by the table, both general and special requirements were analysed. A total of 219 Academic Doctors and 30 academicians were involved in the analysis. In terms of ratios, 29 per cent of the Academic Doctors (63 persons) were found to fully comply with the general minimum requirement, while 38 per cent ( 34 persons) of those in economic sciences fully complied with the special requirements set for economic sciences, and 26 per cent (28 persons) of those dealing with social sciences could fully comply with the special requirements in social sciences. In the case of academicians, 27 per cent ( 8 persons) fully complied with the general minimum requirements and 38 per cent ( 5 persons) with the special requirements in economic sciences, and 21 per cent ( 5 persons) fully complied with the special requirements in social sciences. Similarly to university professors, researchers active in economic sciences complied more than those in social sciences. Also similarly to university professors, in a breakdown by age, junior researchers are more successful in SJR-based publications than senior ones, as the average age of academicians (76 years) is higher than that of Academic Doctors (70 years) (Sasvári and Nemeslaki, 2018).

Regarding special requirements in social sciences, differences are clear between university professors and the scientific committees of Academic Doctors. While in the 
Péter Sasvári, Bálint Teleki, Anna Urbanovics: How to Go on University Professors?

Table 1: The ratio of professors with full compliance with the general and special university professor requirements among the Academic Doctors and academics, in a scientific committee breakdown

\begin{tabular}{l|c|c|c|c}
\hline $\begin{array}{c}\text { Academic } \\
\text { Doctors and } \\
\text { Academicians } \\
\text { Committee }\end{array}$ & $\begin{array}{c}\text { Ratio of academi- } \\
\text { cians fulfilling the } \\
\text { general minimum } \\
\text { requirements }\end{array}$ & $\begin{array}{c}\text { Ratio of academicians } \\
\text { fulfilling the special } \\
\text { minimum require- } \\
\text { ments (in economics) }\end{array}$ & $\begin{array}{c}\text { Ratio of academicians } \\
\text { fulfilling the special } \\
\text { minimum requirements } \\
\text { (in social sciences) }\end{array}$ & Total \\
\hline LAW & $9 \%$ & - & $13 \%$ & 45 \\
\hline CEHR & $60 \%$ & $40 \%$ & - & 5 \\
\hline CBS & $55 \%$ & $55 \%$ & - & 22 \\
\hline CMS & $4 \%$ & - & - & 24 \\
\hline ECO & $38 \%$ & $35 \%$ & $18 \%$ & 37 \\
\hline SCIDS & $18 \%$ & - & $20 \%$ & 11 \\
\hline POL & $20 \%$ & - & - & 15 \\
\hline CRS & $20 \%$ & $20 \%$ & $49 \%$ & 15 \\
\hline CSFS & $40 \%$ & $40 \%$ & $\mathbf{2 6 \%}$ & 10 \\
\hline SOC & $\mathbf{2 9 \%}$ & $\mathbf{2 7 \%}$ & $\mathbf{2 1 \%}$ & 35 \\
\hline Total & $(\mathbf{n}=\mathbf{3 0})$ & $\mathbf{3 8 \%}$ & $\mathbf{2 1 9}$ \\
\hline Academicians & & & & $\mathbf{3 0}$ \\
\hline
\end{tabular}

Source:

analysis of university professors, administrative sciences, media and communication sciences and policing and law enforcement sciences are excess fields, in the case of Academic Doctors SCIDS is the distinct area, which, however, can only be considered in the evaluation of general requirements in the analysis of university professors. Law and political sciences have a higher number of university professors complying with the requirements than social sciences. In the case of the Academic Doctors, however, social sciences rank the highest with 49 per cent, followed by political (20\%), SCIBS $(18 \%)$, and law $(13 \%)$.

Although there are fields on the upgrade, and junior researchers are increasingly open to international publication, however, these findings suggest a structural deficiency.

\section{CONGLUSIONS AND REGOMMENDATIONS}

This paper analyses the general and special minimum publication requirements specified in the new guidelines of HAC on university professors' applications, with effect from 1 September 2019. The performance of the researchers who have received their titles as university professors in the past three years was analysed according to the scientific measures laid down in the new set of requirements. Based on the low 
publication numbers, it has been concluded that there are structural problems and deficiencies.

The most important task is to raise awareness of publication based on the SJRranking, as most of the committees involved have a ranking in their respective fields. The appropriate use of SJR makes publication easily calculable, and a strategy can be built on it.

As the guidelines obviously fit into the processes of the international change of paradigm and require the publication of internationally highly ranked papers, universities should make it a priority to set up incentive systems. Consider the costs of publication (APC costs) and the release of Open Access. In addition, it is necessary to encourage lecturers and researchers, perhaps by the adoption of targeted gratification schemes. Governmental decision-makers might consider to launch a nationwide scientific excellence programme based on the already existing international examples.

Finally, it is important to recognise that the new guidelines on university professors' applications define each step of the career ladder. Some of the Hungarian higher education institutions have already specified international publication requirements as part of the habilitation process, and in the long run this will have an impact on the requirements concerning the Academic Doctors and academics as well. In case the current trend remains, the journal rankings of the scientific committees of HAS should be refashioned to place more emphasis on Q1 and Q2 level journals listed by SJR at the expense of other contents. The distorting factors in the scoring system are also clear: the balancing of scores should be modified to encourage researchers to publish in journals in the upper quartile. In this respect, the higher scores for journals ranked in the SJR system, the lesser the penalty for co-authorship (highlighting the role of the first, the last, and the corresponding author), and the qualitative categories in the international journal ranking (A, B, C, D) should be modified so that they are equal with the Q1, Q2, Q3, Q4 quartiles.

\section{Note}

1 Abbreviations of universities: Andrássy Universitat Budapest (ANNYE); Corvinus University of Budapest (BCE); Budapesti Business School (BGE); Budapest University of Technology and Economics (BME); University of Debrecen (DE); Eszterházy Károly University (EKE); Eötvös Loránd University (ELTE); University of Kaposvár (KE); Central European University (KEE); Károli Gáspár University of the Reformed Church in Hungary (KRE); University of Miskolc (ME); National University of Public Service (NKE); University of Pannonia (PE); Pázmány Péter Catholic University (PPKE); University of Pécs (PTE); University of Sopron (SOE); University of Győr (SZE); Szent István University (SZIE); University of Szeged (SZTE).

\section{REFERENCES}

Act No. XL of 1994 on the Hungarian Academy of Science. https://net.jogtar.hu/jogszabaly?docid=99400040. TV.

Balaton, K. (2019): Reflexiók a „Habitus-metria” cikkhez [Reflections on the article about measuring academic performance]. Statisztikai Szemle, Vol. 97, No. 5, 466-469. 
Bazsa, Gy. (2017): Felfelé a pályán. Hazai oktatói-kutatói karrierállomások [Rising career. Teacher and researcher careers in Hungary]. Magyar Tudomány, Vol. 178, No. 5, 594-606.

BME GTK (2018): PhD fokozat megszerzésének publikációs követelményei [Publication requirements for obtaining a PhD degree]. www.gtk.bme.hu/wp-content/uploads/2020/05/phD-publ.pdf (accessed 18 February 2019).

Castelvecchi, D. (2015): Physics Paper Sets Record with More Than 5,000 Authors. Nature, https://doi. org/10.1038/nature.2015.17567.

Csaba, L.; Szentes, T. and Zalai, E. (2014): Tudományos-e a tudománymérés? Megjegyzések a tudománymetria, az impaktfaktor és MTMT használatához [Is measuring science scientific? Notes on the metrics of sceience, the impact factor and use of MTMT]. Magyar Tudomány, Vol. 175, No. 4, 442-466.

Csapó, B. (2011): Az oktatás tudományos hátterének fejlôdése [Development in the scientific background to education]. Magyar Tudomány, Vol. 172, No. 9, 1065-1076.

Dance, A. (2012): Authorship: Who's on first? Nature, Vol. 489, No. 7417, 591-593, https://doi.org/10.1038/ nj7417-591a.

Dobos, I.; Michalkó, G. and Nováky, E. (2016): Miért nincs királyi út a habilitáció publikációs követelményeinek meghatározására? [Why there is no royal road to the specification of publication requirements for habilitation]. Magyar Tudomány, Vol. 177, No. 11, 1379-1390.

Dusek, T. (2019): A mérés korlátairól a habitus-metria kapcsán [On the limits of measuring academic performance]. Statisztikai Szemle, Vol. 97, No. 5, 458-465.

Gazizova, A. I.; Panfilova, V. M. and Makarova, O. A. (2016): Towards Excellence in Russian Higher Education Institutions. International Journal of Humanities and Cultural Studies, Special Issue July.

Kiss, É. (2014): A tudományos minôsítés nemzetközi gyakorlata egy kérdốves felmérés tükrében [The international practice of academic qualification in light of a questionnaire survey]. Magyar Tudomány, Vol. 175, No. 9, 1129-1135.

Kozma, T. (2011): „Egyetemvállalat” és menedzserizmus ["University corporation” and managerism]. Educatio, Vol. 20, No. 4, 461-471.

Larivière, V.; Haustein, S. and Mongeon, P. (2015): The Oligopoly of Academic Publishers in the Digital Era. PLoS One, Vol. 10, No. 6, https://doi.org/10.1371/journal.pone.0127502.

Larsen, P. O. and Von Ins, M. (2010): The Rate of Growth in Scientific Publication and the Decline in Coverage Provided by Science Citation Index. Scientometrics, Vol. 84, No. 3, 575-603, https://doi. org/10.1007/s11192-010-0202-z.

MAB (2019): A MAB Testületének 2019/5/VII/4. számú határozatával elfogadott Útmutató egyetemi tanári pályázat összeállitásához és értékeléséhez [Resolution No. 2019/5/VII/4. of the HAC on the 'Guideline to the preparation and evaluation of university professor applications']. http://old.mab.hu/web/doc/akkreditacio/ ET_utmutato_20190901.pdf (accessed 18 November 2019).

Nagy, Gy. (2016): Tudománymetria és neveléstudomány [The metrics of science and educational science]. Iskolakultúra, Vol. 26, No. 2, 50-62, https://doi.org/10.17543/iskkult.2016.2.50.

NKFI (2018): Élvonal-Kutatói kiválósági program (KKP_19), támogatott projektek. https://nkfih.gov.hu/palyazoknak/elvonalkutatoi/elvonal-kutatoi (accessed 28 November 2019).

Polónyi, I. (2010): Az akadémiai szféra és az innováció - a hazai felsôoktatás és a gazdasági fejlódés [The academic sector and innovation - Hungarian higher education and economic development]. Új Mandátum Kiadó, Budapest.

Polónyi, I. (2012): A hazai felsôoktatás állami finanszírozásának története, 1990-2011 [History of state financing in Hungarian higher education]. In: Temesi, J. (ed.): Felsôoktatás-finanszírozás. Nemzetközi tendenciák és a hazai helyzet [Funding higher education. International trends and the situation in Hungary]. Aula Kiadó, Budapest.

Papp, J. (2019): Publikáljunk vagy habilitáljunk? [Shall we publish or shall we habilitate?]. Statisztikai Szemle, Vol. 97, No. 5, 490-497.

Redden, E. (2018): Is Econ STEM? Inside Higher Ed, www.insidehighered.com/admissions/article/2018/02/19/economics-departments-reclassify-their-programs-stem-attract-and-help (accessed 21 August 2019). 
Sasvári, P. and Nemeslaki, A. (2018): Az MTA Gazdasági és Jogi Osztály köztestületi tagjai tudományos teljesítményének empirikus elemzése az MTMT alapján [An empirical analysis of academic performance by members of public bodies at HAS Department of Economics and Law, on the basis of MTMT]. Magyar Tudomány, Vol. 179, No. 9, 1399-1412, https://doi.org/10.1556/2065.179.2018.9.13.

Soós, S. (2017): Az impaktfaktor után - mi történik a hazai tudományos kibocsátással a Scimago Journal Rank bevezetésével? Hatások az „impaktfaktoros” publikációk körében [After the impact factor, or what will happen to Hungarian academic output after the adoption of the Scimago Journal Ranking. Effects on "impact factor” publications]. Magyar Tudomány, Vol. 178, No. 5, 583-593.

Wuchty, S.; Jones, B. and Uzzi, B. (2007): The Increasing Dominance of Teams in Production of Knowledge. Science, Vol. 316, No. 5827, 1036-1039, https://doi.org/10.1126/science.1136099.

Zalai, E. (2006): Az MTA doktora címre pályázók habitusvizsgálatának értékelése, 2001-2005 [Evaluation of the academic performance of applicants for the "Doctor of the Academy" title]. Közgazdasági Szemle, Vol. 53, No. 4, 380-386. 